\title{
Relato de Experiência: Mudar para Melhor Acolher na Ubs Santo Abraço
}

\author{
Bezerra, Patricia Melo \\ SPDM - patriciamelob@yahoo.com.br
}

INTRODUÇÃO/OBJETIVOS "Hoje não temos acolhimento", assim informava a equipe da recepção nos dias que o médico não estava presente na UBS Santo Abraço localizada na cidade Azul. Já quando o médico estava presente o acolhimento se dava apenas até às nove da manhã, assim os usuários deveriam chegar até as $07 \mathrm{~h} 15 \mathrm{~min}$. Quem eram estes usuários cadastrados e atendidos nesses primeiros horários matutinos? Qual era a prática acolhedora da equipe de saúde? Então como qualificar um acolhimento que cuide das demandas e das necessidades de saúde dos usuários? Este trabalho tem por finalidade descrever as reflexões e ações da equipe de saúde em Atenção Básica sobre como mudou a prática de acolher na UBS Santo Abraço. Esta transformação objetivava ofertar um serviço com qualidade, equitativo e humanizado. Foram dados nomes fictícios para as instituições e para a cidade citada. METODOLOGIA o caminho para alcançar o objetivo desse trabalho foi realizar uma análise crítica da descrição da transformação do acolher na UBS Santo Abraço, a luz de conceitos e práticas de acolhimento instituídos na literatura. RESULTADOS o acolhimento era realizado pela equipe de saúde da UBS como um atendimento não agendado, pontual, rápido do profissional médico e delimitado a um período do dia, situação que resultava um descomprometimento com o vínculo da assistência longitudinal ao usuário. Tal situação provocava uma exaustão da equipe de saúde e uma dificuldade de avaliar e realizar mudanças. e agora como transpor esta situação? em reuniões gerais foram discutidos e acordados os conceitos e exemplos de práticas de acolhimento. Utilizando o conceito escrito por pesquisadores como Ferreira (1988), Merhy (2005) e do documento-base da política de humanização brasileira (2008) procuraram reconstruir a pratica ato de acolher. Também considerando o acolhimento como o encontro construtivo com quem escuta e enxergar o outro, não apenas a doença, e sim, o ser humano subjetivo na sua integralidade físico, psíquico e social para promoção e produção de saúde sendo o resultado o vínculo para o cuidado de usuários por profissionais de saúde comprometidos. Ademais, o acolher percorre a trajetória do usuário dentro dos serviços e na orientação à rede de assistência saúde. Dessa maneira são atitudes e posturas de uma equipe multidisciplinar capacitada quanto a um atendimento humanizado. Nesse sentido, procuram praticar os conceitos reconstruídos; reelaborar e monitorar o fluxo de acolhimento; capacitar os profissionais quanto as atribuições e funções dos membros das equipes e quanto aos programas e às campanhas vigentes; realizado estudo da demanda espontâneas (descobrindo quem eram os usuários) e uma reformulação contínua das agendas dos profissionais considerando as demandas dos usuários e aspectos epidemiológicos. CONCLUSÕES a prática de acolhimento na UBS Santo Abraço foi transformada por estratégias de gestão do cuidado ao usuário, pois foram traçando novos arranjos organizacionais facilitando o acesso a assistência integral. Foram incorporados, as práticas, os conceitos de acolher por todos, reduzindo a exaustão dos profissionais e melhorando a satisfação dos mesmos com o cuidado ofertado.

Bezerra, Patricia Melo. Relato de Experiência: Mudar para Melhor Acolher na Ubs Santo Abraço. In: Anais do Congresso Internacional de Humanidades \& Humanização em Saúde [= Blucher Medical Proceedings, num.2, vol.1]. São Paulo: Editora Blucher, 2014. ISSN 2357-7282

DOI 10.5151/medpro-cihhs-10682 